\title{
A quantitative field comparison of different types of emergence traps in a stream : general, Trichoptera, Diptera (Limoniidae and Empididae)
}

\author{
H. Malicky ${ }^{1}$
}

Keywords : emergence traps, quantitative emergence, stream, Trichoptera, Plecoptera, Ephemeroptera, Simuliidae, Limoniidae, Empididae.

Emergence traps were operated over three years in a stream near Lunz in southwestern Lower Austria, to find out the differences between eight types of traps. Trichoptera, Plecoptera, Ephemeroptera, Simuliidae, Limoniidae and Empididae were compared quantitatively as whole groups. Trichoptera, Limoniidae and aquatic Empididae were compared at species level. Except for the expected statistical variation, there was wide variation in the number of specimens between groups and species, and also between the trap types, to such a degree that the emergence method appears to be of limited value for productivity or other quantitative studies. The total catch of insects caught in the traps, consisted of freshly emerged adults, aged ovipositing females and many other insects (including terrestrial ones) which entered the traps in unknown ways. The variation may depend on the biology and behaviour of the insects, on the design of the traps and on an unknown number of other factors.

\section{Aspect quantitatif de l'efficacité de différents pièges à émergence dans un ruisseau autrichien}

Mots-clés : pièges à émergence, émergence quantitative, rivière, Trichoptera, Plecoptera, Ephemeroptera, Simuliidae, Limoniidae, Empididae.

Des pièges à émergence ont été utilisés durant trois années dans un ruisseau à Lunz (Basse Autriche ) pour comparer huit types différents de pièges. Les Trichoptera, Plecoptera, Ephemeroptera, Simuliidae, Limoniidae et Empididae sont comparés au niveau des groupes ; Trichoptera, Limoniidae et Empididae aquatiques sont aussi comparés au niveau de l'espèce. A l'exception de la variation statistique prévue, on a observé une telle variation du nombre de specimens entre groupes taxonomiques, entre espèces et entre les différents pièges que la méthode paraît inefficace, au moins pour des études de production et autres études quantitatives. La totalité des insectes capturés dans les pièges se compose d'adultes qui venaient d'émerger, de femelles âgées après la ponte, et de beaucoup d'autres insectes ( $y$ inclus terrestres) qui sont arrivés dans les pièges par des voies inconnues. Cette variation peut dépendre de la biologie et du comportement des insectes, du type de pièges, et d'un nombre inconnu d'autres facteurs.

\section{Introduction}

The emergence method was introduced by Illies (1971) to running water research, and has been widely used since in investigations in many places and regions. In contrast to the usual methods of benthos sampling, it has three major advantages. Firstly, the insects obtained with emergence traps are adults which can be identified more or less easily. The earlier stages collec-

1. Sonnengasse 13, A - 3293 Lunz am See, Austria. ted with bottom sampling are mostly difficult to identify or unidentifiable at species level. Secondly, the emergence method does not destroy the stream bottom so that the community is not disturbed. Thirdly, the method is thought to be surface-related which means that the insects are coming from a defined area of bottom surface, regardless of the depth of the substrate where they have developed; most bottom sampling methods take samples with poorly defined depth distribution. Benthic insects usually go much deeper into the substrate than the collecting devices so that they are under-represented in the samples. In the opinion of research workers, a certain loss by drift of insects from 
the emergence traps is possible, which however was thought to be more or less completely compensated by specimens which have drifted in. Zwick (1977) has shown that the number of freshly emerged males and females of Dictyogenus alpinus was slightly less than the number of their nymphal exuviae left in the trap, but additional aged females were caught so that in the three years operation the total exuviae were 258 , the total adults were 261 .

Thus the emergence method promised good quantitative results, and was proposed by Illies (1972) for production studies. The emergence which is the sum of insects emerging from a defined surface of the stream bottom, was thought to be a fraction of and therefore a measure of secondary production.

I have used emergence traps in several streams over many years in southwestern Lower Austria and in southern Greece ; several papers have been published with the results (Caspers 1983, 1984, Havelka 1978, Illies 1980, Kazimírová 1981, 1982, 1989, Malicky 1976, 1980, 1981, 1989, 1994, Plassmann 1984, Röhner 1978, Wagner w.y., 1980, 1982, Wolda 1983, Zwick 1977).

However, until now no attempt has been made to find out the real efficiency of the method. There were some attempts to improve contradictory results with different trap constructions, by technical measures, and by introducing correcting factors. Several studies had shown that different trap constructions yielded very different results (e.g. Flannagan \& Cobb 1994, Kimerle \& Anderson 1967, LeSage \& Harrison 1979, Morgan \& al. 1963), and proposals for the improvement of trap design were made, either to increase the catch or to estimate which type of trap could be the most reliable (Morgan 1971, Mundie 1971). Steffan (1997) proposed several trap designs to quantify the drift emergence by excluding the bottom emergence. But until now it had not been confirmed if the above assumption, i.e. the strict surface area relation of the catch did really exist.

During the field work with emergence traps, observations were made which were hard to explain on the basis of the original assumptions.

1. - In the emergence traps, insects of clearly terrestrial origin were found relatively often, particularly butterflies and moths. The emergence traps were isolated from the air and from the water surface, but, particularly in the larger greenhouses, this requirement cannot be perfect under field conditions. Moths of the genus Amphipyra, which are known for their habit of hiding in dark crevices, were sometimes found, but moths and butterflies were also caught in the funnel traps which were standing on the bottom of the stream, with their lower edges deep in the water so that no gaps could remain open to the air. There was no other possibility of these moths coming in other than by diving under the water. Even more striking was, particularly in May and June, the presence of terrestrial Empididae, mainly of the genus Hilara. On some days, several thousands were in the traps. Caspers (1984) found 134 species of terrestrial Mycetophilidae in two greenhouses at two stream sites near Lunz in two years which is about one third of the species to be expected in Austria. Löhr (1987) found many terrestrial Syrphidae, and Straka \& Samietz (1992) found over 22.000 terrestrial Empididae of 74 species, mainly Hilara spp., in the total emergence from two greenhouses at one stream, of which 43 were new for the fauna of Thuringia where these studies were made.

Insects of aquatic origin were sometimes noticed which could not be freshly emerged. Already in his first paper, Illies (1971) found several females of Odagmia ornata (Simuliidae) with mature eggs which could not be freshly emerged because for maturation of eggs, a blood meal is mandatory in simuliids. Such observations were regarded as exceptions, and were usually neglected by most authors.

2. - During investigations of the caddisflies of the Schreierbach (Malicky 1976) I observed that some striking daily maxima of their emergence were not correlated with the water temperature (which is almost constant in this stream) but with air temperature. It was not clear how emerging pupae could know the air temperature above the water.

3. - In an unpublished study of the emergence of Trichoptera in a stream which was heavily influenced by human disturbance (Oberer Seebach, Ritrodat area), the most abundant caddis in the traps were females of Micrasema minimum, but all of these hundreds of females had empty abdomens and could therefore not be freshly emerged.

4. - Sometimes species were caught in the emergence traps which could not be found as larvae in the same stream, and are probably not able to develop there. Zwick (1977) suggested that about one third of individuals and 12 of 31 species of Plecoptera came from outside into the greenhouse at Schreierbach, but thought that this was an exception for this, as he thought, extraordinarily turbulent stream. On the other hand, Rüddenklau (1991) found no adults of Silo pallipes and Odontocerum albicorne in emergence traps at sites with a larval density of up to 210 and 110 per square metre. 
5. - Normally the proportion of males and females of a given species is constant in the annual total of a trap, with a predominance of males at the beginning of the flight period, and a dominance of females at the end. The ideal relation would be $1: 1$, but in practice there is some variation, and in most species it is different from this, and varies within narrow limits from the specific figure. At some times, especially in periods of particularly fine weather, an irregular but strong dominance of females was registered in the emergence, e.g. in Philopotamus ludificatus and in Ecclisopteryx guttulata.

The present paper is intended to find out to what extent the results from emergence traps in running waters are useful in basic research (e.g. for studies on productivity) and for applied purposes.

\section{Material and methods}

The study was made in a stream known as the Kothbergbach near Lunz am See, Lower Austria. The coordinates of the locality are $47^{\circ} 52^{\prime} 50^{\prime \prime} \mathrm{N}, 14^{\circ} 59^{\prime} 19^{\prime \prime} \mathrm{E}$, and the site is in an altitude of $640 \mathrm{~m}$ where the stream is 6 to $8 \mathrm{~m}$ broad, with a discharge of about $600 \mathrm{l} / \mathrm{sec}$ at low water flow. The adjacent rocks are dolomite whose weathering results in small, sharp-edged gravel and sand which cover the bottom. Conductivity is about $300 \mu \mathrm{S}_{20}$, and the water is calcium-rich. The catchment area is covered by forest with dominant spruce and pine, and a few interspersed farms with meadows, but with no field cultivation. The mean of water temperature is $12^{\circ} \mathrm{C}$ in the summer months (June to September), with maxima at about $15-18^{\circ} \mathrm{C}$, and the mean during winter (January to March) is about $2.5^{\circ} \mathrm{C}$, with minima at $0.3^{\circ} \mathrm{C}$. Temperature variation within one week is about $5-6^{\circ} \mathrm{C}$ at all seasons.
This stream was selected because it has a fauna rich in species, and because its size and discharge were suitable for all the types of emergence traps used; small enough to be covered by a greenhouse over its full width, shallow enough for the funnel traps, and large enough for the swimming traps.

The traps were placed in the middle of a straight stretch of about $100 \mathrm{~m}$ length of the stream, which appeared homogenous in sediment, velocity, width and insolation, of this otherwise meandering stream. The position of the individual traps which remained in place over the whole period is shown in Fig. 1.

The following traps were used (see also table 1) :

1.- A greenhouse (abbreviated $\mathrm{GH}$ ) which covered the total width of the stream (Fig. 2) and included both banks, with a covered surface of $180 \times 590 \mathrm{~cm}, 2 \mathrm{~m}$ high, and with a saddle roof. It was placed on two beams which were fixed on both banks. Walls and roof were of transparent sheets of polystyrene. Underneath it was closed to the banks with panels, and sealed from the air above the water with large aprons of polyethylene, filled with heavy stones so that their lower edges dipped into the water over the whole width of the stream. The emerging insects in the GH were collected manually with a modified vacuum cleaner which had a collecting chamber filled with $70 \%$ ethanol. During the warm season collecting was normally on Monday, Wednesday and Friday, but during the cold season only occasionally when in warmer periods emergence was observed. More frequent collection had probably increased the total catch according to the experience of Sprules (1947) and Ringe (1974).

2. - A floating trap was called Novara (abbreviated NO) (Fig. 3) in honour of the Imperial Austrian Friga-

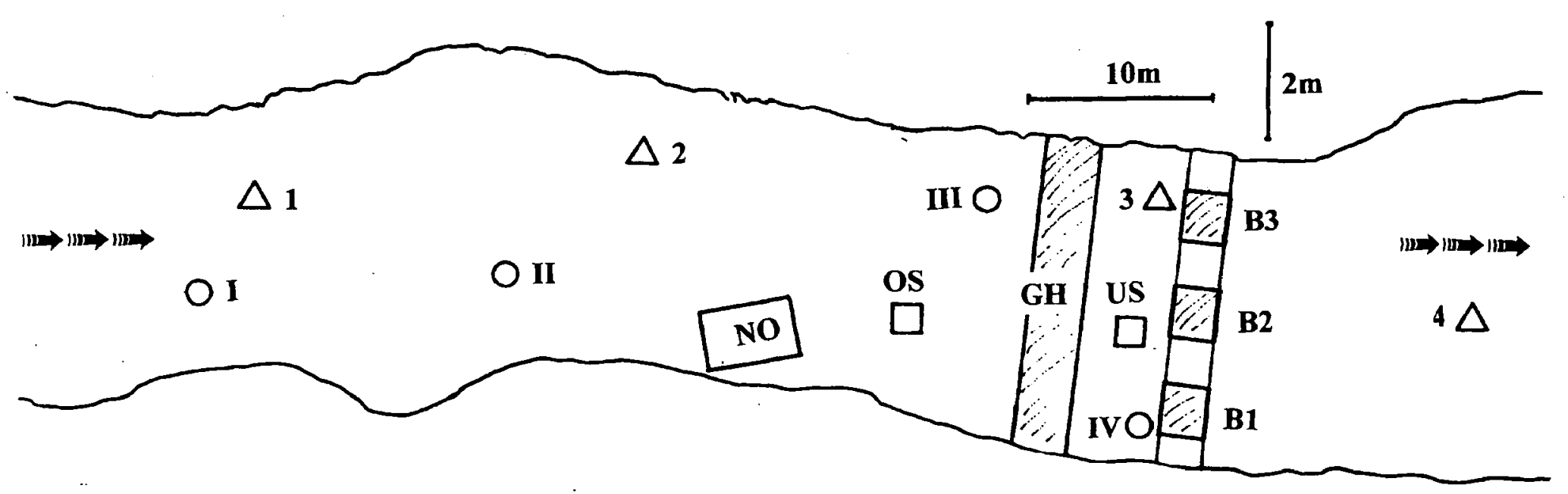

Fig. 1. Arrangement of the traps in the study area.

Fig. 1. Disposition des pièges sur la zone d'étude. 
Table 1. Synopsis of the investigated trap types.

Tableau 1. Tableau synoptique des pièges étudiés.

\begin{tabular}{|c|c|c|c|c|c|c|c|c|}
\hline trap & GH & NO & $\mathbf{B}$ & $\begin{array}{l}\text { OS, } \\
\text { US }\end{array}$ & $\begin{array}{l}T \\
I, I I I\end{array}$ & $\begin{array}{l}T \\
\text { II,IV }\end{array}$ & $\begin{array}{l}T \\
1,3\end{array}$ & $\begin{array}{l}T \\
2,4\end{array}$ \\
\hline Bottom surface $\mathrm{m}^{2}$ & 10,6 & 2 & 1 & 1 & 0,28 & 0,28 & 0,1 & 0,1 \\
\hline $\begin{array}{l}\text { Manual collecting } \\
\text { in ethanol }\end{array}$ & + & + & + & & & & & \\
\hline $\begin{array}{l}\text { Automatic collecting } \\
\text { in ethyleneglycol }\end{array}$ & & & & + & + & + & + & + \\
\hline Standing on bottom & & & & & + & + & + & + \\
\hline Floating & & + & & + & & & & \\
\hline Dipping & + & & + & & & & & \\
\hline Anchored & & & & & & & + & + \\
\hline Free standing & & & & & + & + & & \\
\hline Wide opening $52 \mathrm{~mm}$ & & & & + & + & & + & \\
\hline Narrow opening $24 \mathrm{~mm}$ & & & & & & + & & + \\
\hline
\end{tabular}

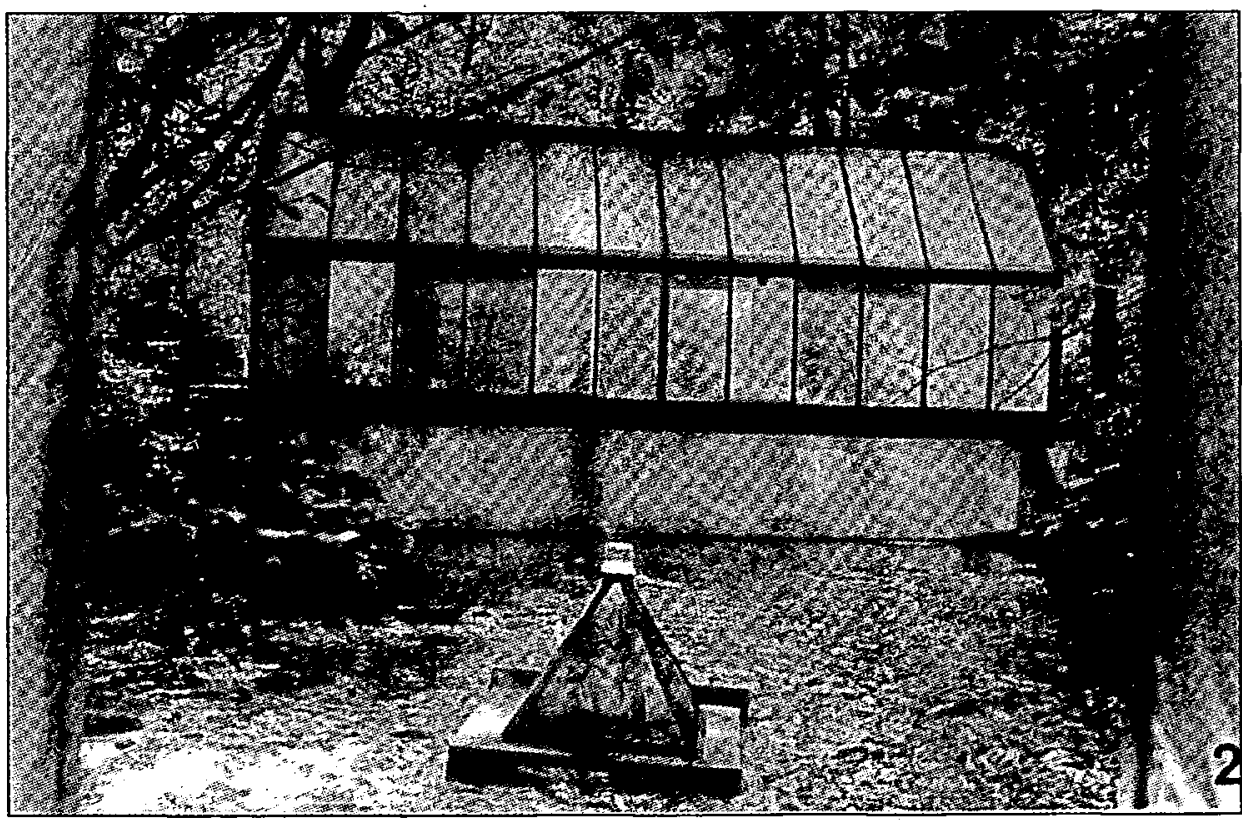

Fig. 2. The greenhouse trap $(\mathrm{GH})$.

Fig. 2. Le piège serre (GH). 
te Novara which made a well known research voyage around the world in 1857-59. This trap was made of an iron frame construction of $1 \times 2 \mathrm{~m}$ bottom surface and $2 \mathrm{~m}$ height, covered with transparent polyethylene walls and small ventilation windows covered with $1 \mathrm{~mm}$ mesh-size nylon gauze. This cage was built on a rectangular floating body made of zinc-plated iron sheet and filled with commercially available plastic foam, large enough to carry the cage and the collector. This trap was secured to trees near the stream by steel cables. Collecting was as in $\mathrm{GH}$.

3. - Three cages, placed on a bridge (abbreviated B1, B2, B3 : Fig. 4) with a surface of $1 \times 1 \mathrm{~m}$ and $2 \mathrm{~m}$ high, made from the same materials as NO. As in GH, their distance from the stream bottom was constant. Up- and downstream sides under the bridge were of polyethyle-

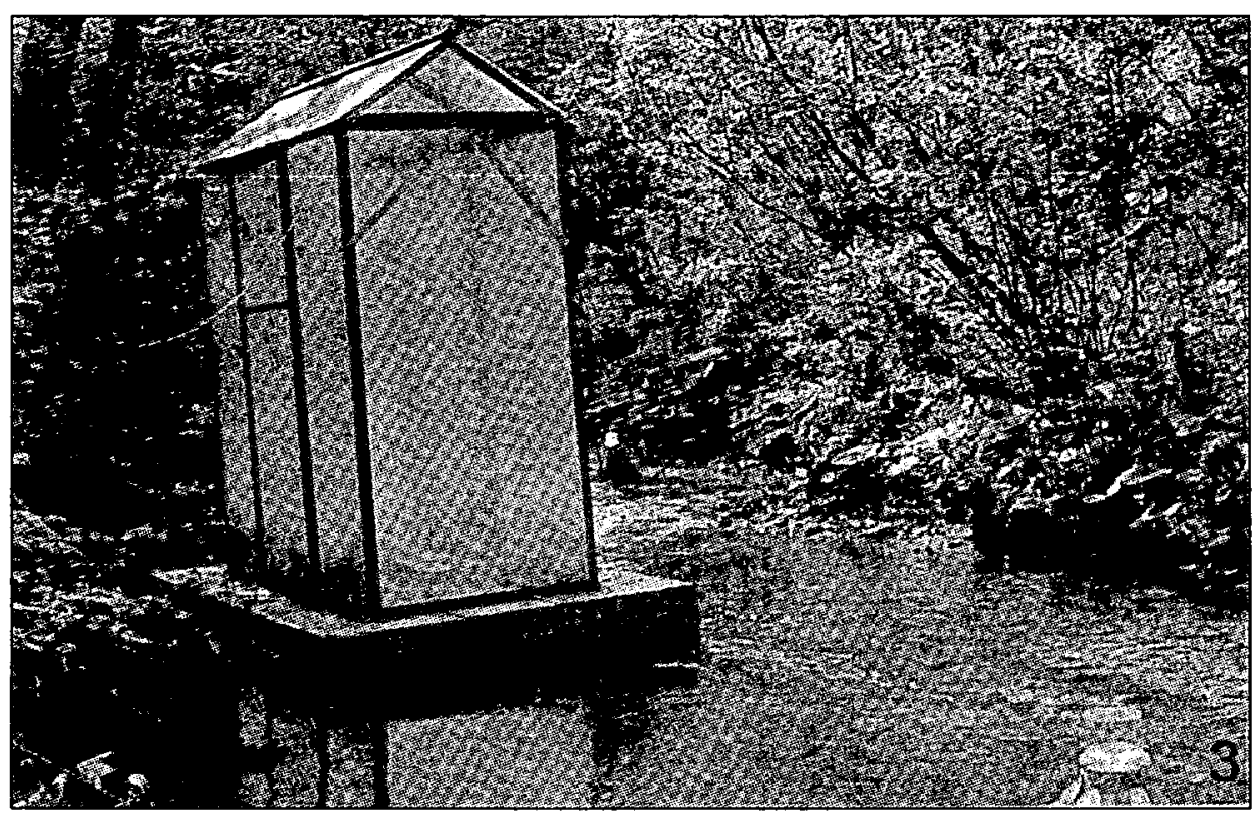

Fig. 3. The floating trap Novara (NO).

Fig. 3. Le piège flottant Novara (NO).

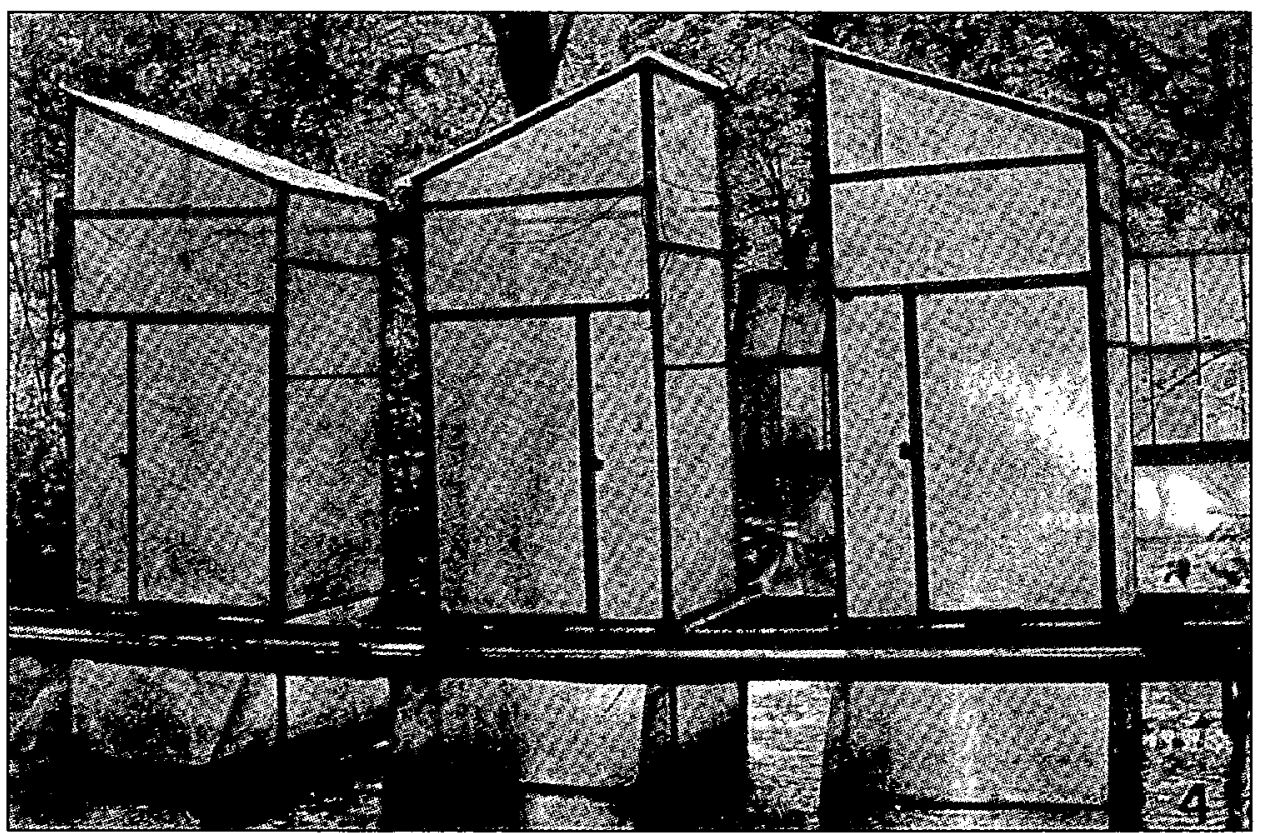

Fig. 4. The greenhouse traps B1, B2 and B3.

Fig. 4. Les pièges serre B1, B2 et B3. 
ne aprons as in $\mathrm{GH}$, but the lateral parts were closed with polystyrene plates which reached into the water but did not touch the stream bottom. Collecting was as in $\mathrm{GH}$ and NO.

4. - Two floating traps (abbreviated OS, US : Fig. 5) of pyramid shape with $1 \mathrm{~m}^{2}$ bottom surface, mounted on a floating board made of strong wooden panels, fastened by steel cables to trees. The cage consisted of an iron framework, covered with $1 \mathrm{~mm}$ mesh-size nylon gauze. At the top of the pyramid, there was a collecting container of acrylic glass which had a central tube to allow the insects to enter, surrounded by a gutter filled with ethylene glycol. This container was emptied once a week.

5. - Four round-bottom funnel-shaped cages (Fig. 6) of $60 \mathrm{~cm}$ diameter, $60 \mathrm{~cm}$ high, made of iron and covered with $1 \mathrm{~mm}$ mesh-size gauze made of stainless steel. In an earlier version, nylon gauze was used but it was not strong enough under field conditions. At the top a container of acrylic glass was fastened, as in OS and US, and emptied once a week. These traps were free standing on the stream bottom, and they were stable

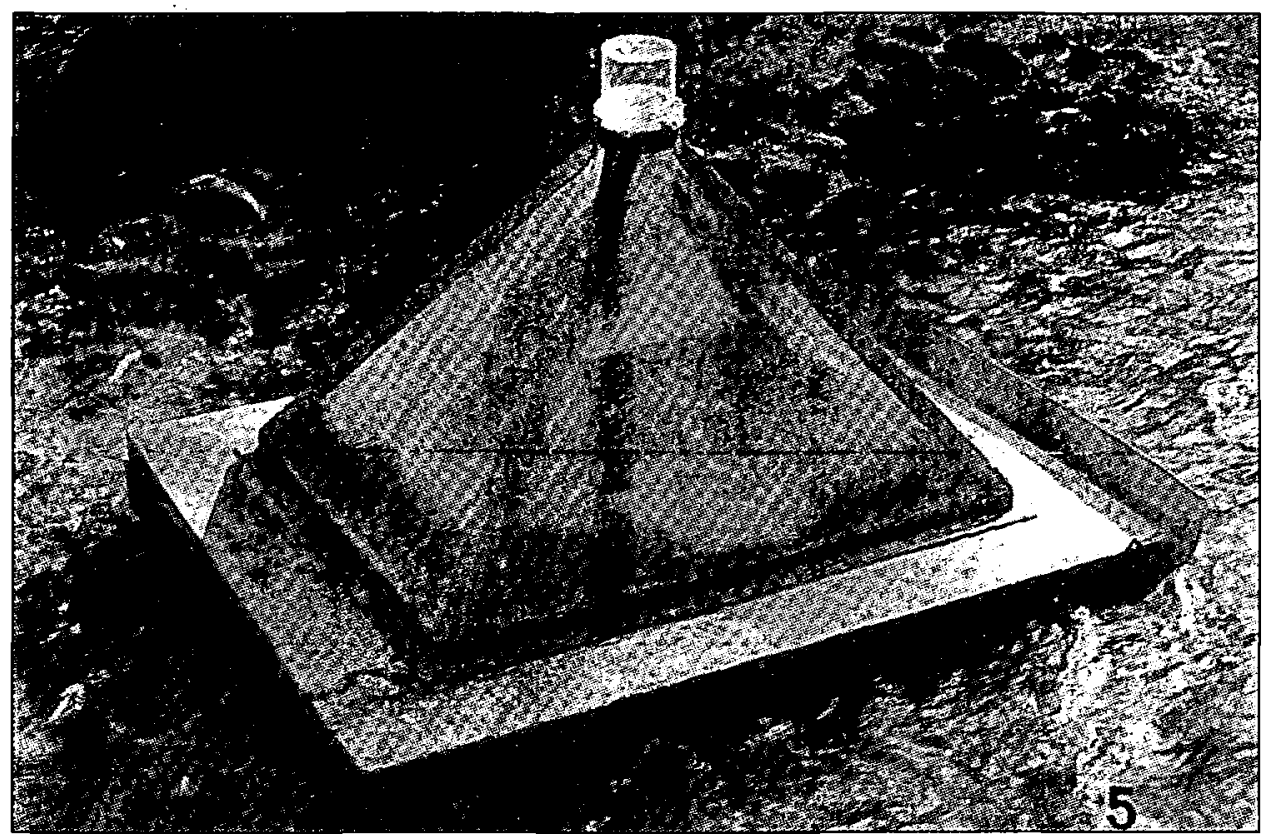

Fig. 5. One of the floating traps OS, US.

Fig. 5. Un des pièges flottants OS, US.

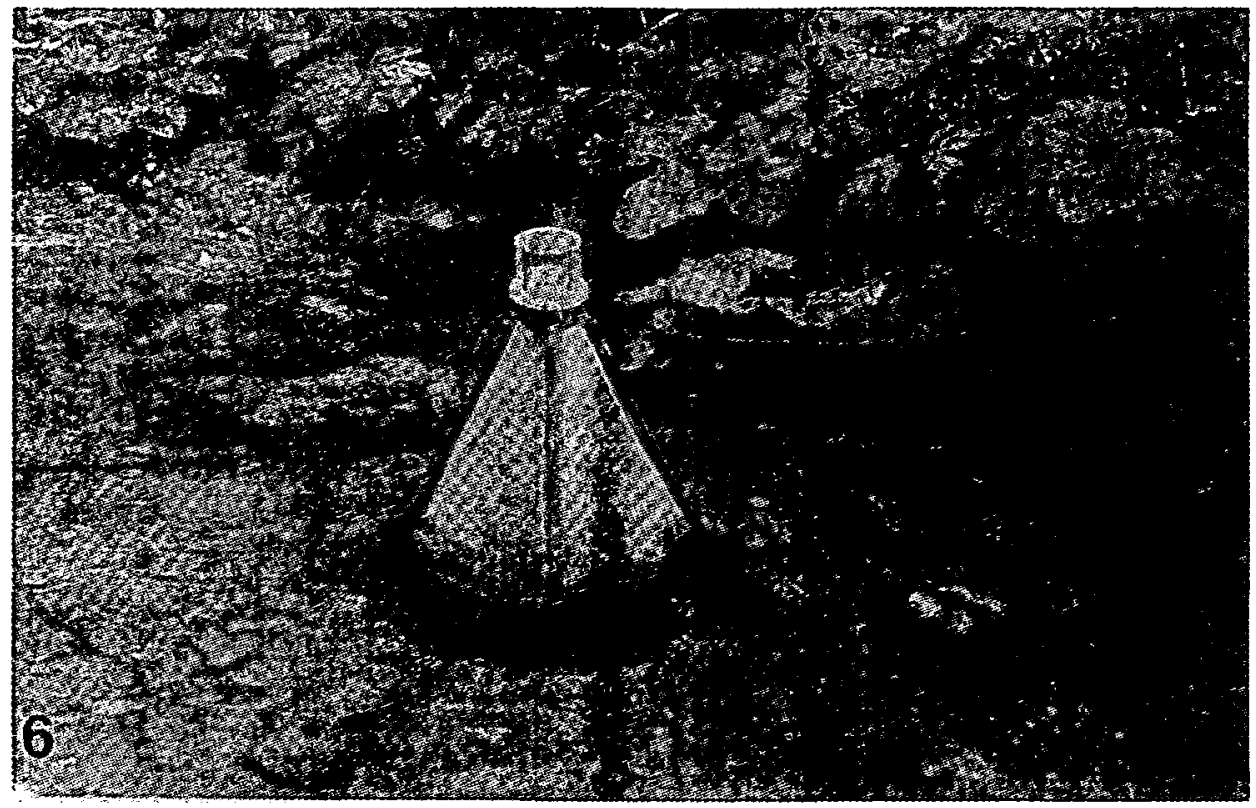

Fig. 6. One of the funnel traps with round bottom (T I - T IV).

Fig. 6. Un des pièges en forme d'entonnoir à fond rond (T I - T IV). 
enough at normal water flow. At higher water velocities they were easily swept away, so they were fastened by a steel cable to a tree, and the other end of the cable was fastened near the top of the funnel which meant that at high water flow the whole funnel drifted automatically to the safe edge of the stream. This meant that in such cases the sample of the week was lost, but such occasional losses were inevitable. The abbreviations are T I to T IV. There were two variations (Fig. 7) :
$5 \mathrm{a}$ - Two of these traps (TI, TII) had a wider opening of the central tube in the collecting container of $52 \mathrm{~mm}$ diameter.

5 b - The other two (TII, T IV) had a narrower opening of $24 \mathrm{~mm}$. This was an attempt to find out whether the diameter of the opening could influence the catch.

6. - Four pyramid-shaped funnels (Fig. 8), similar to no. 5 , with a triangular bottom of $40 \times 50 \mathrm{~cm}$ which ga-

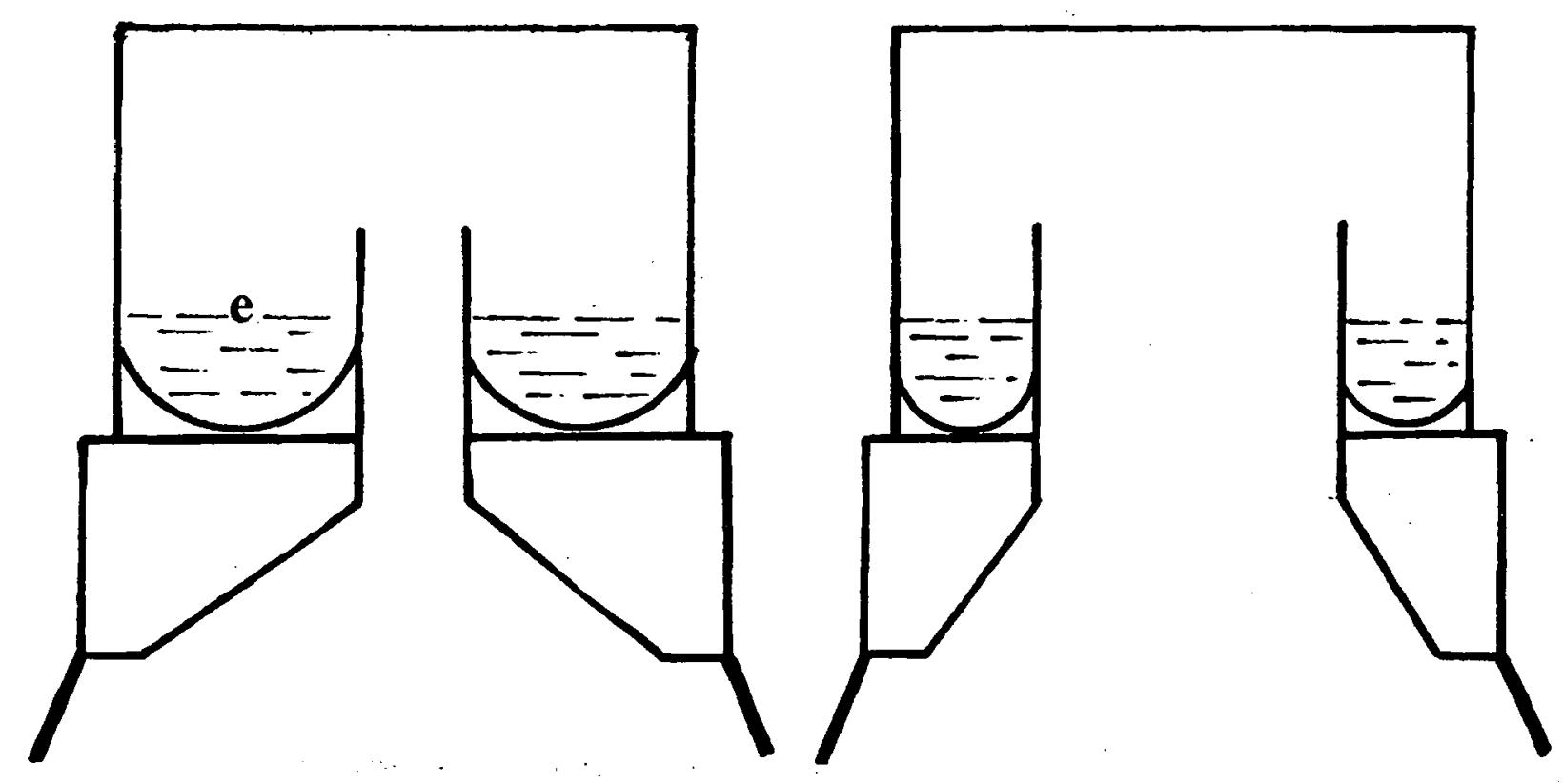

Fig. 7. One of the funnel traps with triangular bottom (T 1 - T 4).

Fig. 7. Un des pièges en forme d'entonnoir à fond triangulaire (T 1 - T 4).

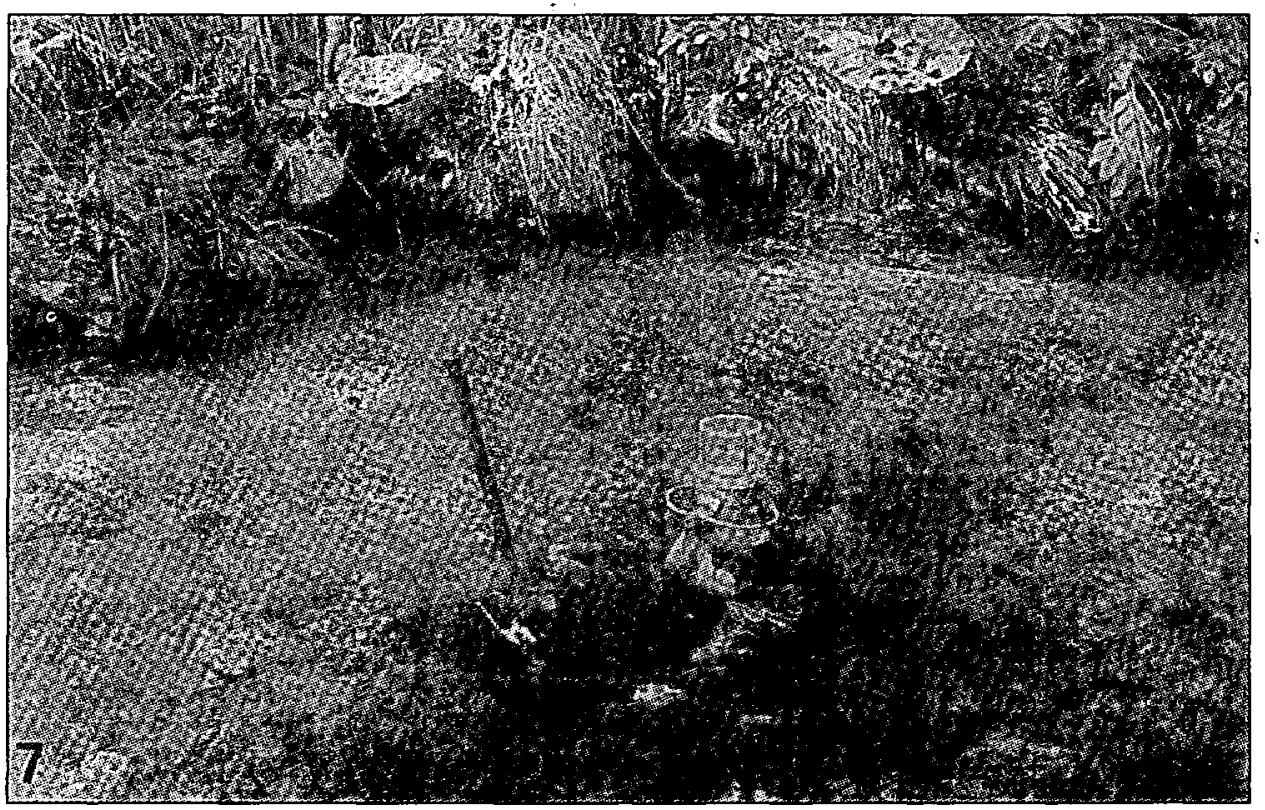

Fig. 8. The collecting containers of the funnel traps, with narrow (left) and wide (right) opening of the central tube. $\mathrm{e}$ : ethylene glycol.

Fig. 8. Les récipients collecteurs des pièges en forme d'entonnoir, à orifice étroit (à gauche) et large (à droite) du tube central. 
ve a surface of $0,1 \mathrm{~m}^{2}$, and $35 \mathrm{~cm}$ high, with the same type of collecting containers as before. These traps were made of very strong iron, and the tip of the triangle pointed upstream. The traps were standing free on the bottom, but were fastened from a ring of the bottom frame to a strong iron bar which was driven deep into the bottom. At high water flow the trap could be totally flooded but was strong enough to stay in position ; the catch of the week was likewise lost, and the collecting container was occasionally broken by drifting logs. Abbreviations T1 to T4. As in 5, two widths of the opening tube were used :

$6 \mathrm{a}-\mathrm{T} 1$ and T3 with a diameter of $52 \mathrm{~mm}$,

$6 \mathrm{~b}-\mathrm{T} 2$ and T4 with a diameter of $24 \mathrm{~mm}$.

The traps were exposed continuously from April 1985 to October 1987, OS and US only from April 1986 onwards.

The traps GH and B1-3 were not in operation between August and October 1985. On 5 August 1985 there was a big flood. The trap NO had been fastened by two steel cables consisting of many fine filaments. These had been corroded by the damp air in only three months, and broke, so that NO crashed into $\mathrm{GH}$ and B1-3 and destroyed them. NO was recovered with minor damage, but B and $\mathrm{GH}$ had to be completely rebuilt. After this experience, all steel cables were replaced by strong zinc-plated iron wires which proved to be secure.

\section{Results and discussion}

The detailed data of Trichoptera, Empididae, Limoniidae and Dixidae are stored in the Austrian Biogeographical Databank Zobodat (Biozentrum Linz, J.W. Kleinstraße 73, A - $4040 \mathrm{Linz}$ ) and are available there. Here I give only the annual totals which are necessary for discussion.

For the evaluation I did not use any statistical methods because they are not relevant. The plan of the field work was to get results under realistic conditions and to find out how efficient the method was, and not to make constant mistakes to get smooth results. Readers are however free to use the data for their own calculations, and I shall be pleased to supply details to interested workers.

\subsection{Annual totals of emergence of selected insect groups}

In Tables 2-7, annual totals per surface unit in the different traps of Trichoptera, Plecoptera, Ephemeroptera, Simuliidae, Limoniidae and aquatic Empididae are given, regardless of the numbers of species. The totals may be easily reconstructed by multiplication of the numbers by the bottom surface in Table 1 .

This simple arrangement gives a first approach to the problem, together with the number of species of Trichoptera, Limoniidae and Empididae in table 8.

Remember there was no catch in GH and B 1-3 between August and October 1985 (see above), but even without considering this gap, one could not find it in the tables, where the figures are so variable without any a clear trend. I therefore used the 1985 data as they were. The conclusions will not be affected by this gap.

It is not surprising that the results from the T-traps are more variable than those from the larger traps because their surfaces and totals are smaller. The data from the B traps are far less variable and would, in a subjective impression, be suitable for a statistical analysis. However, the comparison of the two traps OS and US raises the question how is it possible that two traps of identical construction, and placed a few metres apart are so extremely different in their results. This is especially true for Trichoptera and Plecoptera and will become even more apparent in the detailed evaluation.

Comparing the different types of traps, the numbers from $\mathrm{GH}$ are, in all groups except Limoniidae, clearly lower than in the other traps. An explanation may be that the insects can escape easily through the open bottom, but this is not confirmed by the results of NO and $B$ with the same open bottom. Trap NO has much higher numbers of Trichoptera than the other traps, but for the other groups they are similar. The B traps have higher numbers for Plecoptera and Limoniidae, and the T traps have caught far more Plecoptera and distincly more Ephemeroptera than the other traps. The traps OS and US have caught clearly less, except Trichoptera.

The methods of collecting, i.e. manual collection by vacuum cleaner, or automatic trapping, show no striking differences, only in Plecoptera are the figures higher for automatic trapping (because there were so many in the T-traps.).

OS caught more Plecoptera, while US caught more Trichoptera and Simuliidae.

Surprisingly, comparison of different tube widths in the T traps shows a clearly higher catch of Trichoptera, Plecoptera and Simuliidae in the narrower type ; the reason for this is unknown. Maybe the insects can easier escape through the wider opening ? Likewise, I have no explanation for the fact that in the triangular 
Table 2. Summary of the results on Trichoptera.

Tableau 2. Tableau synoptique des résultats sur les Trichoptera.

\begin{tabular}{|c|c|c|c|c|}
\hline Trichoptera $\mathrm{N} / \mathrm{m}^{2} . \mathrm{a}$ & 1985 & 1986 & 1987 & Mean 1985-87 \\
\hline GH & 352 & 214 & 170 & 245 \\
\hline NO & 990 & 944 & 1081 & 1005 \\
\hline B 1 & 253 & 487 & 957 & \\
\hline B 2 & 476 & 465 & 685 & \\
\hline B 3 & 499 & 413 & 573 & \\
\hline Mean B & & & & 534 \\
\hline $\mathrm{T}\left(\begin{array}{ll}\Delta & 1\end{array}\right.$ & 140 & 80 & 270 & \\
\hline$T(\Delta) \quad 2$ & 440 & 440 & 1230 & \\
\hline$T(\Delta) \quad 3$ & 190 & 480 & 410 & \\
\hline$T(\Delta) \quad 4$ & 520 & 2150 & 3460 & \\
\hline$T(0) \quad 1$ & 35 & 67 & 106 & \\
\hline $\mathrm{T}(0) \quad$ II & 198 & 297 & 216 & \\
\hline$T(0) \quad I I I$ & 227 & 135 & 191 & \\
\hline$T(O) ~ I V$ & 428 & 188 & 266 & \\
\hline Mean $\mathrm{T}(\Delta)$ & 323 & 788 & 1343 & 818 \\
\hline Mean $T(0)$ & 222 & 172 & 195 & 196 \\
\hline Mean T Wide op. & 148 & 191 & 244 & 194 \\
\hline Mean T Narrow op. & 397 & 1538 & 130 & 688 \\
\hline Mean $\mathrm{T}$ & & & & 507 \\
\hline os & & 58 & 148 & 103 \\
\hline US & & 280 & 1371 & 826 \\
\hline Mean Hand collected & 514 & 505 & 693 & 571 \\
\hline Mean Trapped & 272 & 418 & 767 & 486 \\
\hline
\end{tabular}

Table 3. Summary of the results on Plecoptera.

Tableau 3. Tableau synoptique des résultats sur les Plecoptera.

\begin{tabular}{|c|c|c|c|c|}
\hline Plecoptera N/m ${ }^{2} . a$ & 1985 & 1986 & 1987 & Mean 1985-87 \\
\hline $\begin{array}{l}\text { GH } \\
\text { NO }\end{array}$ & $\begin{array}{l}590 \\
893\end{array}$ & $\begin{array}{r}754 \\
2315\end{array}$ & $\begin{array}{l}201 \\
490\end{array}$ & $\begin{array}{r}515 \\
1233\end{array}$ \\
\hline $\begin{array}{l}\text { B } 1 \\
\text { B } 2 \\
\text { B 3 } \\
\text { Mean B }\end{array}$ & $\begin{array}{l}2729 \\
4444 \\
4611\end{array}$ & $\begin{array}{l}1622 \\
2426 \\
3204\end{array}$ & $\begin{array}{r}506 \\
345 \\
1083\end{array}$ & 2330 \\
\hline $\begin{array}{lc}\mathrm{T}(\Delta) & 1 \\
\mathrm{~T}(\Delta) & 2 \\
\mathrm{~T}(\Delta) & 3 \\
\mathrm{~T}(\Delta) & 4 \\
\mathrm{~T}(0) & 1 \\
\mathrm{~T}(0) & \mathrm{II} \\
\mathrm{T}(0) & \mathrm{III} \\
\mathrm{T}(0) & \mathrm{IV}\end{array}$ & $\begin{array}{r}7170 \\
11220 \\
7130 \\
10040 \\
1825 \\
3405 \\
4326 \\
7795\end{array}$ & $\begin{array}{r}2950 \\
9620 \\
10960 \\
7970 \\
2018 \\
4691 \\
1989 \\
6418\end{array}$ & $\begin{array}{r}2370 \\
3850 \\
2990 \\
7430 \\
878 \\
2761 \\
1083 \\
1398\end{array}$ & \\
\hline $\begin{array}{l}\text { Mean T }(\Delta) \\
\text { Mean T }(O) \\
\text { Mean T Wide op. } \\
\text { Mean T Narrow op. } \\
\text { Mean T }\end{array}$ & $\begin{array}{l}8890 \\
4338 \\
5113 \\
8115\end{array}$ & $\begin{array}{l}7876 \\
3780 \\
4479 \\
7175\end{array}$ & $\begin{array}{l}4160 \\
1530 \\
1830 \\
3860\end{array}$ & $\begin{array}{l}6975 \\
3216 \\
3807 \\
6383 \\
5096\end{array}$ \\
\hline $\begin{array}{l}\text { OS } \\
\text { US }\end{array}$ & & $\begin{array}{l}583 \\
340\end{array}$ & $\begin{array}{r}1303 \\
175\end{array}$ & $\begin{array}{l}943 \\
258\end{array}$ \\
\hline Mean Hand collected & 2653 & 2064 & 525 & 1747 \\
\hline Mean Trapped & 6614 & 4754 & 2424 & 4597 \\
\hline
\end{tabular}


Table 4. Summary of the results on Ephemeroptera.

Tableau 4. Tableau synoptique des résultats sur les Ephemeroptera.

\begin{tabular}{|c|c|c|c|c|}
\hline Ephemeroptera $\mathrm{N} / \mathrm{m}^{2}$.a & 1985 & 1986 & 1987 & Mean 1985-87 \\
\hline GH & 325 & 325 & 149 & 266 \\
\hline NO & 881 & 556 & 502 & 646 \\
\hline B 1 & 221 & 667 & 939 & \\
\hline B 2 & 194 & 945 & 466 & \\
\hline B 3 & 135 & 599 & 239 & \\
\hline Mean B & & & & 489 \\
\hline$T(\Delta) \quad 1$ & 1540 & 2690 & 440 & \\
\hline $\mathrm{T}(\Delta) \quad 2$ & 980 & 2230 & 120 & \\
\hline $\mathrm{T}(\Delta) \quad 3$ & 1030 & 2670 & 620 & \\
\hline$T(\Delta) \quad 4$ & 570 & 4930 & 520 & \\
\hline$T(0) \quad 1$ & 520 & 1211 & 372 & \\
\hline$T(0) \quad \|$ & 368 & 517 & 312 & \\
\hline$T(0) \quad I I I$ & 414 & 616 & 358 & \\
\hline$T(O)$ IV & 457 & 1264 & 163 & \\
\hline Mean T $(\Delta)$ & 1030 & 3130 & 425 & 1528 \\
\hline Mean T (O) & 440 & 902 & 301 & 548 \\
\hline Mean $T$ Wide op. & 876 & 1797 & 448 & 1040 \\
\hline Mean T Narrow op. & 594 & 2235 & 279 & 1036 \\
\hline Mean $T$ & & & & 1038 \\
\hline OS & & 166 & 230 & 198 \\
\hline US & & 497 & 90 & 294 \\
\hline Mean Hand collected & 351 & 618 & 459 & 476 \\
\hline Mean Trapped & 735 & 1679 & 323 & 912 \\
\hline
\end{tabular}

Table 5. Summary of the results on Simuliidae.

Tableau 5. Tableau synoptique des résultats sur les Simuliidae.

\begin{tabular}{|c|c|c|c|c|}
\hline Simuliidae $\mathrm{N} / \mathrm{m}^{2}$.a & 1985 & 1986 & 1987 & Mean 1985-87 \\
\hline GH & 149 & 15 & 60 & 75 \\
\hline NO & 598 & 111 & 263 & 324 \\
\hline B 1 & 94 & 158 & 200 & \\
\hline B 2 & 115 & 224 & 189 & \\
\hline B 3 & 105 & 118 & 172 & \\
\hline Mean $\mathrm{B}$ & & & & 153 \\
\hline $\mathrm{T}(\Delta) \quad 1$ & 220 & 10 & 90 & \\
\hline$T(\Delta) \quad 2$ & 490 & 80 & 200 & \\
\hline $\mathrm{T}(\Delta) \quad 3$ & 490 & 70 & 260 & \\
\hline$T(\Delta) \quad 4$ & 780 & 120 & 520 & \\
\hline$T(0) \quad I$ & 64 & 11 & 103 & \\
\hline$T(0) \|$ & 195 & 110 & 216 & \\
\hline$T(0) \quad I I I$ & 188 & 14 & 198 & \\
\hline $\mathrm{T}(\mathrm{O}) \mathrm{IV}$ & 315 & 21 & 184 & \\
\hline Mean T $(\Delta)$ & 495 & 70 & 268 & 278 \\
\hline Mean T (O) & 191 & 39 & 175 & 135 \\
\hline Mean T Wide op. & 241 & 26 & 163 & 143 \\
\hline Mean T Narrow op. & 445 & 83 & 280 & 269 \\
\hline Mean $T$ & & & & 206 \\
\hline os & & 12 & 39 & 26 \\
\hline US & & 43 & 135 & 89 \\
\hline Mean Hand collected & 212 & 125 & 177 & 171 \\
\hline Mean Trapped & 343 & 49 & 195 & 196 \\
\hline
\end{tabular}


Table 6. Summary of the results on Limoniidae.

Tableau 6. Tableau synoptique des résultats sur les Limoniidae.

\begin{tabular}{|c|c|c|c|c|}
\hline Limoniidae $\mathrm{N} / \mathrm{m}^{2}$.a & 1985 & 1986 & 1987 & Mean 1985-87 \\
\hline $\begin{array}{l}\text { GH } \\
\text { NO }\end{array}$ & $\begin{array}{r}215 \\
83\end{array}$ & $\begin{array}{l}43 \\
18\end{array}$ & $\begin{array}{l}48 \\
36\end{array}$ & $\begin{array}{r}102 \\
46\end{array}$ \\
\hline $\begin{array}{l}\text { B } 1 \\
\text { B } 2 \\
\text { B } 3 \\
\text { Mean B }\end{array}$ & $\begin{array}{r}52 \\
439 \\
160\end{array}$ & $\begin{array}{r}128 \\
110 \\
70\end{array}$ & $\begin{array}{r}111 \\
55 \\
32\end{array}$ & 129 \\
\hline $\begin{array}{ll}T(\Delta) & 1 \\
T(\Delta) & 2 \\
T(\Delta) & 3 \\
T(\Delta) & 4 \\
T(0) & 1 \\
T(O) & \text { II } \\
T(0) & \text { III } \\
T(O) & \text { IV }\end{array}$ & $\begin{array}{r}40 \\
40 \\
40 \\
160 \\
14 \\
14 \\
35 \\
124 \\
92\end{array}$ & $\begin{array}{r}0 \\
0 \\
10 \\
0 \\
18 \\
25 \\
4 \\
67\end{array}$ & $\begin{array}{r}0 \\
0 \\
0 \\
120 \\
4 \\
11 \\
21 \\
0\end{array}$ & \\
\hline $\begin{array}{l}\text { Mean T }(\Delta) \\
\text { Mean T }(O) \\
\text { Mean T Wide op. } \\
\text { Mean T Narrow op. } \\
\text { Mean T }\end{array}$ & $\begin{array}{l}70 \\
66 \\
55 \\
82\end{array}$ & $\begin{array}{r}3 \\
29 \\
8 \\
23\end{array}$ & $\begin{array}{r}30 \\
9 \\
6 \\
33\end{array}$ & $\begin{array}{l}34 \\
35 \\
23 \\
46 \\
34\end{array}$ \\
\hline $\begin{array}{l}\text { OS } \\
\text { US }\end{array}$ & & $\begin{array}{l}1 \\
6\end{array}$ & $\begin{array}{l}7 \\
9\end{array}$ & $\begin{array}{l}4 \\
8\end{array}$ \\
\hline Mean Hand collected & 190 & 74 & 56 & 107 \\
\hline Mean Trapped & 68 & 31 & 17 & 39 \\
\hline
\end{tabular}

Table 7. Summary of the results on Empididae.

Tableau 7. Tableau synoptique des résultats sur les Empididae.

\begin{tabular}{lrrrc}
\hline Empididae N/m2 .a & 1985 & 1986 & 1987 & Mean 1985-87 \\
\hline GH & 28 & 32 & 16 & 25 \\
NO & 44 & 28 & 62 & 45 \\
B 1 & 12 & 35 & 60 & \\
B 2 & 19 & 16 & 56 & \\
B 3 & 20 & 15 & 31 & \\
Mean B & & & & 29 \\
T工 & 71 & 18 & 83 & 57 \\
\hline
\end{tabular}

traps $\mathrm{T}$ more insects of all groups were trapped than in the very similar traps $T$ with round bottoms. So we must accept the paradoxical result that the clearest differences in the catches were between trap designs with minor differences in construction.

Comparing the results for the different insect groups, the following conclusions are evident.

The total catch, which is the total of the real catch in these traps, evidently cannot be the result of one natural phenomenon alone and can therefore not be considered calculable according to a single calculable pro- cess. If the variation of the catch between the different traps was caused only by the natural variation within the study site, a reasonable average could be obtained by statistical methods. But this is clearly not so. If, for instance, just in the largest trap GH fewer specimens per surface unit were caught than in all other traps, there must be at least one unknown additional factor. Relatively unimportant details, such as the round or triangular bottom of a trap, or a slightly wider or narrower entrance opening to the collecting container, result in the clearest differences in the catch ; this must also ha- 
Table 8 . Number of species in the traps per year.

Tableau 8. Nombre annuel d'espèces dans les pièges.

\begin{tabular}{lrrrrrrrrr}
\hline & \multicolumn{3}{c}{ Trichoptera } & \multicolumn{1}{c}{ Limoniidae } & \multicolumn{3}{c}{ Empididae } \\
& 1985 & 1986 & 1987 & 1985 & 1986 & 1987 & 1985 & 1986 & 1987 \\
\hline GH & 34 & 31 & 31 & 23 & 33 & 21 & 5 & 7 & 7 \\
NO & 27 & 25 & 25 & 8 & 8 & 4 & 6 & 6 & 5 \\
B 1 & 18 & 18 & 25 & 6 & 13 & 12 & 5 & 5 & 8 \\
B 2 & 19 & 18 & 19 & 8 & 8 & 9 & 5 & 5 & 7 \\
B 3 & 20 & 21 & 20 & 5 & 10 & 5 & 3 & 2 & 3 \\
T 1 & 6 & 6 & 11 & 2 & 0 & 0 & & & \\
T 2 & 13 & 10 & 11 & 1 & 0 & 0 & & & \\
T 3 & 10 & 9 & 8 & 1 & 2 & 0 & & & \\
T 4 & 9 & 5 & 11 & 1 & 0 & 2 & & & \\
T I & 3 & 8 & 13 & 1 & 1 & 1 & & none \\
T II & 13 & 15 & 17 & 1 & 3 & 2 & & & \\
T III & 13 & 12 & 12 & 1 & 1 & 2 & & & \\
T IV & 13 & 16 & 16 & 1 & 1 & 0 & & & \\
OS & & 15 & 14 & & 1 & 1 & & & \\
US & & 15 & 15 & & 1 & 4 & & & \\
\hline
\end{tabular}

ve a reason in the presence of additional unknown factors, and this must also be supposed if two traps with the same condition (OS and US) had enormous differences in their total catch.

Emergence is an indication of the stream-based production of the immature stages. It is clear that some relation must exist between emergence biomass and benthos secondary production. Where else otherwise could the adults come from ? Total catch, which means the total collected insects in the traps, is not a result of the benthic production alone, but is influenced by an unknown number of other factors of which some may be in the emerging behaviour of the species, and others in the construction of traps, but these are probably not all unknown factors.

In a preliminary presentation of these results at a meeting, I had (Malicky 1989) expressed my doubts as to whether emergence traps provide any quantitative measure for a given stream. Statzner \& Resh (1993) in a large-scale evaluation of data from the literature, did not support these doubts. Based on 18 cases of welldefined species in individual streams, they concluded that a statistically significant relation exists between benthic production and emergence (1.c., p. 68, fig. 3). This is surprising and worth a closer examination. Their data include four species of Simuliidae in which the relation between emergence and benthic production is in a narrow range between $1: 3,8$ and $1: 5,3$. Almost the same relation was found in one species of Ephemeroptera. For a second ephemeropteran species however, in three different stream sites, this relation was $1: 1,1,1: 2$ and $1: 3,7$ respectively, and the only caddisfly had a relation of $1: 16$. Even in these few cases which probably represent the total in the world literature, the relation in different species varies between $1: 1$ and $1: 16$, and within one species at different sites between $1: 1,1$ and $1: 3,7$ ! I don't think that it is correct to use here the term "statistically significant" even if this resulted from the use of any formal method. If in those few studied instances the relation between benthic production and emergence shows such a wide variation, how can we predict anything quantitative for the mixture of hundreds or thousands of species found in the emergence traps in field work. We should rather remember the conclusion by Benedetto Castro (1975) : "Es ist aber möglich, aus der Emergenz, deren produktionsbiologischer Stellenwert relativ gering ist, die Gesamtproduktion der Art abzuleiten. Voraussetzung dafür bleibt jedoch ein intensives autökologisches Studium jeder Art."

\subsection{Trichoptera}

All caddisflies were identified to species and sexed. The complete list of species will be published elsewhere. In Table 9 I give the individuals per square meter and the percentage of females for the 12 most abundant species. The results of the $8 \mathrm{~T}$-traps are lumped together here for a better survey.

It is evident for all species that the trap GH caught the lowest numbers per surface unit, and trap NO the highest ; I have no explanation for this. The presence 
Table 9. Comparison of the 12 most abundant Trichoptera species.

Tableau 9. Comparaison des 12 espèces de Trichoptères les plus abondantes.

\begin{tabular}{|c|c|c|c|c|c|c|c|c|c|c|c|c|c|c|c|c|}
\hline & \multicolumn{2}{|c|}{$\mathrm{GH}$} & \multicolumn{2}{|c|}{ NO } & \multicolumn{2}{|c|}{ B1 } & \multicolumn{2}{|c|}{ B2 } & \multicolumn{2}{|c|}{ B3 } & \multicolumn{2}{|c|}{$\sum \mathrm{T}$} & \multicolumn{2}{|c|}{ OS } & \multicolumn{2}{|c|}{ US } \\
\hline & $\mathrm{N} / \mathrm{m}^{2}$ & $\%$ 우 & $\mathrm{N} / \mathrm{m}^{2}$ & $\%$ & $\mathrm{~N} / \mathrm{m}^{2}$ & $\%$ & $\mathrm{~N} / \mathrm{m}^{2}$ & $\%$ 움 & $\mathrm{N} / \mathrm{m}^{2}$ & $\%$ ㅇ & $\mathrm{N} / \mathrm{m}^{2}$ & $\%$ & $\mathrm{~N} / \mathrm{m}^{2}$ & $\%$ 요 & $\mathrm{N} / \mathrm{m}^{2}$ & $\%$ \\
\hline \multicolumn{17}{|c|}{ Rhyacophila aurata } \\
\hline 1985 & 18 & 50 & 102 & 36 & 13 & 31 & 20 & 35 & 94 & 46 & 31 & 81 & & & & \\
\hline 1986 & 8 & 40 & 29 & 41 & 6 & 67 & 12 & 50 & 15 & 47 & 6 & 75 & 0 & 0 & 5 & 40 \\
\hline 1987 & 4 & 43 & 50 & 40 & 8 & 25 & 15 & 33 & 20 & 60 & 16 & 100 & 4 & 75 & 7 & 86 \\
\hline \multicolumn{17}{|c|}{ Rhyacophila tristis } \\
\hline 1985 & 69 & 54 & 84 & 45 & 47 & 60 & 64 & 53 & 90 & 51 & 20 & 50 & & & & \\
\hline 1986 & 16 & 45 & 23 & 50 & 52 & 37 & 41 & 29 & 61 & 39 & 13 & 55 & 0 & 0 & 8 & 50 \\
\hline 1987 & 20 & 31 & 39 & 51 & 133 & 29 & 88 & 20 & 35 & 28 & 8 & 27 & 6 & 67 & 71 & 59 \\
\hline \multicolumn{17}{|c|}{ Rhyacophila vulgaris } \\
\hline 1985 & 2 & 52 & 28 & 32 & 0 & 0 & 0 & 0 & 4 & 50 & 8 & 45 & & & & \\
\hline 1986 & 8 & 37 & 10 & 40 & 7 & 57 & 6 & 67 & 14 & 29 & 5 & 86 & 11 & 64 & 17 & 29 \\
\hline 1987 & 10 & 50 & 64 & 41 & 27 & 48 & 40 & 43 & 32 & 34 & 14 & 67 & 4 & 25 & 2 & 100 \\
\hline \multicolumn{17}{|c|}{ Glossosoma conformis } \\
\hline 1985 & 25 & 52 & 42 & 42 & 9 & 56 & 14 & 28 & 43 & 44 & 23 & 82 & & & & \\
\hline 1986 & 14 & 60 & 50 & 56 & 31 & 61 & 42 & 57 & 19 & 63 & 16 & 83 & 2 & 100 & 26 & 88 \\
\hline 1987 & 4 & 50 & 47 & 82 & 50 & 56 & 75 & 53 & 54 & 63 & 27 & 80 & 3 & 100 & 15 & 80 \\
\hline \multicolumn{17}{|c|}{ Hydroptila ivisa } \\
\hline 1985 & 20 & 42 & 124 & 46 & 29 & 45 & 81 & 44 & 9 & 67 & 27 & 44 & & & & \\
\hline 1986 & 2 & 48 & 21 & 39 & 11 & 73 & 3 & 33 & 13 & 61 & 3 & 100 & 1 & 100 & 5 & 80 \\
\hline 1987 & 2 & 40 & 17 & 62 & 17 & 41 & 0 & 0 & 7 & 29 & 1 & 100 & 0 & 0 & 1 & 100 \\
\hline \multicolumn{17}{|c|}{ Philopotamus ludificatus } \\
\hline 1985 & 9 & 46 & 24 & 36 & 8 & 25 & 6 & 67 & 44 & 23 & 3 & 75 & & & & \\
\hline 1986 & 7 & 64 & 18 & 19 & 1 & 100 & 5 & 60 & 6 & 50 & 2 & 100 & 0 & 0 & 0 & 0 \\
\hline 1987 & 2 & 65 & 9 & 56 & 4 & 25 & 11 & 73 & 7 & 29 & 13 & 42 & 1 & 0 & 4 & 75 \\
\hline \multicolumn{17}{|c|}{ Hydropsyche dinarica } \\
\hline 1985 & 2 & 35 & 11 & 57 & 2 & 100 & 2 & 50 & 3 & 100 & 2 & 100 & & & & \\
\hline 1986 & 4 & 72 & 64 & 92 & 16 & 50 & 19 & 42 & 7 & 86 & 1 & 100 & 3 & 100 & 4 & 75 \\
\hline 1987 & 3 & 75 & 66 & 81 & 28 & 61 & 45 & 60 & 9 & 89 & 9 & 86 & 11 & 100 & 2 & 50 \\
\hline Hydro & yche te & uis & & & & & & & & & & & & & & \\
\hline 1985 & 24 & 55 & 132 & 84 & 21 & 86 & 34 & 65 & 13 & 84 & 31 & $98^{\circ}$ & & & & \\
\hline 1986 & 19 & 62 & 212 & 91 & 40 & 33 & 58 & 43 & 44 & 64 & 21 & 91 & 14 & 100 & 37 & 64 \\
\hline 1987 & 14 & 49 & 76 & 80 & 123 & 66 & 53 & 66 & 54 & 54 & 33 & 98 & 15 & 93 & 1 & 0 \\
\hline Tino & ves & & & & & & & & & & & & & & & \\
\hline 1985 & 70 & 46 & 189 & 46 & 44 & 28 & 40 & 43 & 145 & 46 & 29 & 47. & & & & \\
\hline 1986 & 31 & 47 & 171 & 44 & 149 & 43 & 64 & 42 & 52 & 58 & 28 & 49 & 5 & 80 & 10 & 40 \\
\hline 1987 & 37 & 47 & 217 & 41 & 159 & 48 & 63 & 49 & 168 & 43 & 31 & 40 & 38 & 58 & 40 & 60 \\
\hline Micr & ni & num & & & & & & & & & & & & & & \\
\hline 1985 & 46 & 39. & 189 & 37 & 38. & 32 & 169 & 43 & 15 & 27 & $47-$ & $\ldots 63$ & $\cdots$ & $\ldots$ & & \\
\hline 1986 & 34 & 48 & 208 & 34 & 56 & 55 & 130 & 47 & 105 & 63 & 200 & 89 & 2 & 0 & 136 & 97 \\
\hline 1987 & 31 & 50 & 423 & 37 & 241 & 59 & 213 & 58 & 109 & 60 & 283 & 97 & 56 & 36 & 1338 & 88 \\
\hline Silo & & & & & & & & & & & & & & & & \\
\hline 1985 & 10 & 34 & 24 & 40 & 14 & 29 & 13 & 46 & 5 & 80 & 6 & 44 & & & & \\
\hline 1986 & 27 & 41 & 51 & 38 & 50 & 46 & 52 & 40 & 56 & 50 & 12 & 33 & 7 & 43 & 14 & 50 \\
\hline 1987 & 9 & 52 & 17 & 36 & 105 & 64 & 21 & 19 & 22 & 59 & 7 & 60 & 1 & 0 & 11 & 27 \\
\hline Odol & $u m$ al & icom & & & & & & & & & & & & & & \\
\hline 1985 & 20 & 26 & 19 & 26 & 13 & 23 & 6 & 0 & 9 & 11 & 3 & 0 & & & & \\
\hline 1986 & 18 & 32 & 17 & 18 & 25 & 24 & 9 & 56 & 9 & 33 & 13 & 42. & 3 & 0 & 6 & 50 \\
\hline 1987 & 7 & 31 & 18 & 8 & 32 & 7 & 12 & 8 & 14 & 22 & 11 & 37 & 4 & 0 & 1 & 0 \\
\hline
\end{tabular}


of species is however highest in trap GH (see table 8). Variation between the traps B 1-3 was expected, but there is no clear indication as to which of the three had the highest numbers: comparing the annual totals, trap $\mathrm{B} 1$ has the highest values in 10 instances, $\mathrm{B} 2$ in 11 and B3 in 15 instances. Both floating traps OS and US were less efficient than the other traps. The T-traps show the expected high variation because of their small bottom surfaces, but give in total reasonable quantities.

Table 8 contains also the male/female relations, expressed by the percentage of females. It is generally supposed that the proportions of males and females in insect species are normally equal, although this should be investigated for every species by a detailed study of representative quantities of field-collected pupae. For our discussion it is enough to suppose that a percentage of females around $50 \%$ means that this sample consists of freshly emerged specimens. For Odontocerum albicorne this percentage in the tables is always distinctly lower ; it is not known whether in this species so few females really emerge. In all other species the females are, if the samples are large enough, normally between 40 and $50 \%$, particularly clearly seen in the traps GH and NO. This concerns only the annual sums ; the temporal distribution of both sexes is unequal because at the beginning of the period more males were found, and at its end more females ; proterandry is a well-known phenomenon in insects. But even in the traps $\mathrm{GH}$ and $\mathrm{NO}$, and more distinctly in $\mathrm{T}$ and $\mathrm{S}$ we find often much higher proportions of females, e.g. in species of Hydropsyche, Philopotamus ludificatus, Hydroptila ivisa, Glossosoma conformis and Micrasema minimum. The results of the latter are useful to be discussed in detail.

\section{Observations on Micrasema minimum.}

As in other brachycentrids, freshly emerged and aged females of M.minimum are easily separable by the different conditions of their abdomen. Freshly emerged females have a large and well-filled abdomen. After oviposition the abdomen is empty, flat and almost transparent, like the empty skin of a sausage. Females with flat abdomens in the catch are therefore not freshly emerged, but are several days old.

Table 10 gives a detailed survey of the annual totals.

The freshly emerged specimens are the males and the "full" females. Their female percentage is normally between 25 and $50 \%$ which means a fairly good correspondence; these are field collections with an unknown number of variable factors, and not laboratory experiments under controlled conditions.

Table 11 compares freshly emerged (male and female) and aged (female) specimens per surface unit:

Comparing the freshly emerged specimens, which are the males and the "full" females, the different traps in the same year show the above mentioned relations : big differences between the different trap constructions and positions of the traps, but comparing the same trap over three years the rates stay in the roughly same dimension, and their year-to-year differences may correspond with real variation of production. The difference between OS and US is enormous, but has the same trend between 1986 and 1987.

Comparing, on the other hand, the numbers of "empty" females, we get a different, very irregular pattern which does not correspond with the pattern discussed above. Note, in particular, the difference between OS and US : in OS in both years not a single specimen, but in US in 1987 more than a thousand specimens !

$$
\begin{aligned}
& \text { Table 10. Emergence of Micrasema minimum, totals. } \\
& \text { Q. Tableau 10. Emergence de Micrasema minimum, nombres totaux. }
\end{aligned}
$$

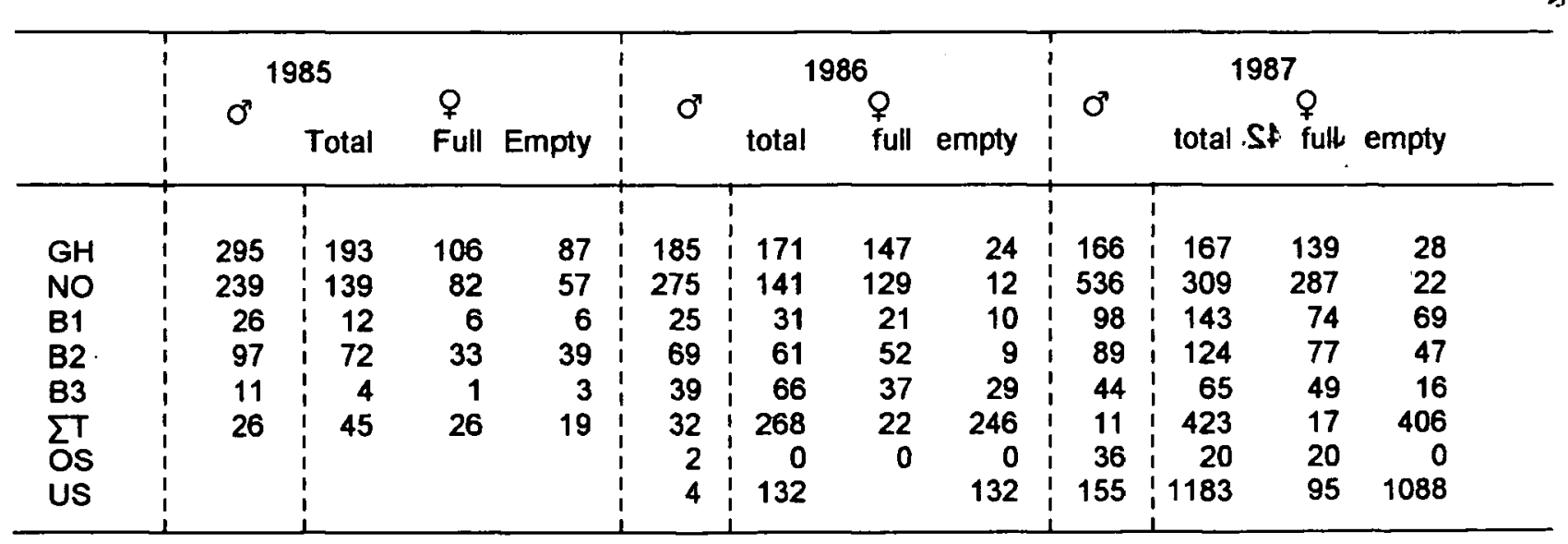


Table 11. Emergence of Micrasema minimum, totals per square unit.

Tableau 11. Emergence de Micrasema minimum, nombres par unités de surface.

\begin{tabular}{lrrrrrr}
\hline & males + & "full" & females & "empty" & females & only \\
& 1985 & 1986 & 1987 & 1985 & 1986 & 1987 \\
\hline GH & 38 & 31 & 29 & 9 & 2 & 3 \\
NO & 161 & 202 & 412 & 29 & 6 & 11 \\
B1 & 32 & 46 & 172 & 6 & 10 & 69 \\
B2 & 130 & 121 & 166 & 39 & 9 & 47 \\
B3 & 12 & 76 & 93 & 3 & 29 & 16 \\
IT & 35 & 36 & 19 & 13 & 164 & 271 \\
OS & & 2 & 56 & & 0 & 0 \\
US & & 4 & 250 & & 132 & 1088 \\
\hline
\end{tabular}

It does not make sense to speculate about the reasons. They are certainly to be found in the behaviour of the insects, of which little is known. One clear result is however evident: what we call emergence of a species consists of a minimum of two phenomena : firstly, the emergence behaviour of freshly emerged specimens, and secondly of the oviposition behaviour of females. These phenomena show completely different patterns. In the case of Micrasema minimum they are easy to recognise, as in other brachycentrids and other insects such as Plecoptera. In most other caddisflies this is not immediately obvious, although in some species the sex proportions in the traps suggest a similar diving and ovipositing behaviour, such as in Philopotamus ludificatus or Ecclisopteryx guttulata.

The presence of so many empty females supports the idea that if female percentages are much higher than 50, a large proportion of these are not freshly emerged but include many aged females. This applies certainly also to species in which it is not so easy to see whether a female is freshly emerged or aged. Therefore it means that a high proportion of the total catch is not freshly emerged. In the traps $T$ and $S$ this applies to more species than usual, as can been seen in table 9 . With a slight exaggeration one can say that the traps $T$ and $S$ are mainly catching aged females and are therefore not very useful as "emergence" traps.

One possible explanation for this is in the trap design. Ovipositing females may easily escape in the traps $\mathrm{GH}, \mathrm{NO}$ and B through the open bottom because in these greenhouses collecting is only every 2-3 days, but in the containers of traps $\mathrm{T}$ and $\mathrm{S}$ they are definitely caught. If the collection in GH, NO and B had been made every day or several times a day, the proportion of aged females might be higher.

In practical work it makes no sense to deduce a defined percentage of females from the total catch because the proportion of aged females is very variable and subject to the influence of an unknown number of factors. It is of course possible to dissect every single female to find out if it is freshly emerged or aged; this may certainly be made in detailed studies but is not practicable for large catches.

\subsection{Limoniidae}

More than 60 species of Limoniidae were collected, but with one exception, only in small numbers which did not allow a quantitative comparison. Antocha vitripennis was abundant enough, and its figures are given in table 12. The comparison of the traps shows high variation which is however not consistent with the years ; in the hand-collected traps there were distinctly higher numbers. The percentage of females was generally between about 40 and 60 , except in the traps with low totals, which means a fairly balanced sex ratio. Nevertheless, a variation between 13 and 106 specimens per $\mathrm{m}^{2}$ in different traps is far beyond the confidence for production studies, so that the same conclusions as above may also apply for the Limoniidae.

\subsection{Empididae}

About 20 species of aquatic Empididae were collected. Only males are used in the tables because the females could not be identified safely. The five most abundant species are presented in Table 13. As in the other groups, the figures are very variable between the traps and also between the years which is however not so striking because the totals are low. The figures from OS and US are omitted here because they were too low.

The higher numbers in the funnel traps of Wiedemannia bohemani and $W$. wachtli are striking. This may be a result of different behaviour. They are on the wing mainly during the cold season, so it is also possible that they were less active in the hand-collected traps and therefore were sometimes overlooked. 
Table 12. Emergence of Antocha vitripennis (Limoniidae).

Tableau 12. Emergence d'Antocha vitripennis (Limoniidae).

\begin{tabular}{|c|c|c|c|c|c|c|c|c|c|c|c|c|c|c|c|c|}
\hline & \multicolumn{2}{|c|}{$\mathrm{GH}$} & \multicolumn{2}{|c|}{ NO } & \multicolumn{2}{|c|}{ B1 } & \multicolumn{2}{|c|}{ B2 } & \multicolumn{2}{|c|}{ B3 } & \multicolumn{2}{|c|}{$\Sigma \mathrm{T}$} & \multicolumn{2}{|c|}{ OS } & \multicolumn{2}{|c|}{ US } \\
\hline & $\mathrm{N} / \mathrm{m}^{2}$ & $\% \%$ & $\mathrm{~N} / \mathrm{m}^{2}$ & $\%$ \% & $\mathrm{N} / \mathrm{m}^{2}$ & $\% ?$ & $\mathrm{~N} / \mathrm{m}^{2}$ & $\%$ & $\mathrm{~N} / \mathrm{m}^{2}$ & $\% ?$ & $\mathrm{~N} / \mathrm{m}^{2}$ & $\% 9$ & $\mathrm{~N} / \mathrm{m}^{2}$ & $\% 9$ & $\mathrm{~N} / \mathrm{m}^{2}$ & $\% ?$ \\
\hline 1985 & 203 & 58 & 88 & 46 & 43 & 42 & 432 & 43 & 156 & 40 & 67 & 45 & & & & \\
\hline 1986 & 32 & 62 & 13 & 40 & 106 & 63 & 103 & 43 & 57 & 67 & 5 & 75 & 1 & 100 & 6 & 50 \\
\hline 1987 & 41 & 42 & 34 & 42 & 83 & 41 & 38 & 47 & 24 & 46 & 8 & 42 & 7 & 28 & 4 & 75 \\
\hline
\end{tabular}

Table 13. Emergence of Empididae.

Tableau 13. Emergence des Empididae.

\begin{tabular}{|c|c|c|c|c|c|c|}
\hline Empididae $\mathrm{N} / \mathrm{m}^{2}$ & GH & NO & B1 & B2 & B3 & $\Sigma T$ \\
\hline \multicolumn{7}{|c|}{ Chelifera concinnicauda } \\
\hline 1985 & 1 & 5 & 1 & 3 & 1 & 0 \\
\hline 1986 & 9 & 4 & 13 & 5 & 4 & 0 \\
\hline 1987 & 7 & 16 & 40 & 8 & 19 & 0 \\
\hline
\end{tabular}

Chelifera trapezina

$\begin{array}{rrrrrrr}1985 & 6 & 8 & 0 & 7 & 6 & 0 \\ 1986 & 16 & 15 & 7 & 7 & 10 & 1 \\ 1987 & 2 & 10 & 3 & 6 & 9 & 1\end{array}$

$\begin{array}{lrrrrrr}\text { Wiedemannia austriaca } & & & & \\ 1985 & 7 & 6 & 2 & 7 & 0 & 6 \\ 1986 & 1 & 1 & 8 & 1 & 0 & 1 \\ 1987 & 1 & 2 & 0 & 2 & 0 & 0\end{array}$

$\begin{array}{lrrrrrr}\text { Wiedemannia bohemani } & & & & & \\ 1985 & 15 & 22 & 5 & 1 & 13 & 26 \\ 1986 & 5 & 8 & 6 & 2 & 0 & 4 \\ 1987 & 5 & 20 & 11 & 29 & 2 & 38\end{array}$

\begin{tabular}{lrrrrrr} 
Wiedemannia wachtli & & & & & & \\
1985 & 1 & 4 & 3 & 0 & 0 & 19 \\
1986 & 1 & 1 & 0 & 0 & 0 & 10 \\
1987 & 2 & 15 & 1 & 9 & 0 & 30 \\
\hline
\end{tabular}

\section{Conclusion}

The results from different construction types of emergence traps are so variable that these traps are quite useless for quantitative studies. In a related study, I have shown (Malicky 2002, in press) that a high proportion of the insects do not come from the bottom below the trap.

Readers may now ask which trap construction is the "best", or which one gives the most reliable results. For a particular study, one has first to make comparative studies to find out which construction is the most appropriate for this particular problem. According to the present study, none of the constructions is the best fitted for all possible purposes, and it is unlikely to find a construction which gives "true" results. Attempts to keep the variation at a minimum i.e. to make always the same mistake to get statistical significance of results are not recommended. But this applies also to any other field methods. 


\section{Acknowledgements}

First of all I have to thank Erich Lanzenberger who took care of the traps over many years and who has done most of the collecting ; in addition he has sorted and counted many samples. He did much of the construction work on the traps. For their technical assistance I want also to thank Alfred Aigner, Fritz Aigner and Arnold Leichtfried. Collections were sometimes made by a number of occasional helpers. Hans Mendl has identified the Limoniidae. Rüdiger Wagner has identified the Empididae (and Psychodidae and Dixidae which are not considered in this paper because of their low numbers). M. Ian Crichton has corrected the English text. To all of them I owe my sincere thanks.

\section{Dedication}

I dedicate this paper to the memory of Professor Joachim Illies. He has not only stimulated my work on emergence traps but he has also helped me in a substantial way over many years. I find it a pity that until now, almost twenty years after his sadly early death, no editor has been found to dedicate to him a volume with contributions from his many students and friends, despite his eminence in this field. It is inevitable that some of his ideas may be modified in the light of new findings. In the present paper I feel somewhat guilty in this respect, in particular after my publication on zonation in a tropical stream (Malicky \& Chantaramongkol 1995). He was certainly one of the first to realise the need to modify hypotheses while continuing research. Many ideas in science would probably never have come forward without his initiative.

\section{References}

Benedetto Castro L. 1975. - Ökologie und Produktionsbiologie von Agapetus fuscipes Curt. im Breitenbach 1971-1972. - Arch. Hydrobiol., Suppl. 45 : 305-375.

Caspers N. 1983. - Chironomiden-Emergenz zweier Lunzer Bäche, 1972. - Arch. Hydrobiol., Suppl. 65 : 484-549.

Caspers N. 1984. - Mycetophiliden aus Lunz, Niederösterreich (Diptera, Nematocera, Mycetophilidae). - Entomofauna (Linz), $5: 173-205$

Flannagan J.F. \& Cobb D.G. 1994. - Studies on some riverine insect emergence traps : effects of sampling frequency and trap design. - Can. Tech. Rep. Fish. Aquat. Sci., 1995 ; IV + 10 pp.

Havelka P. 1978. - Dasyhelea erici n.sp., eine neue Ceratopogonide aus der Teichbach-Emergenz (Diptera, Ceratopogonidae). $-Z$. Arbgem. Öst. Ent., $30: 62-64$

Illies J. 1971. — Emergenz 1969 im Breitenbach. - Arch. Hydrobiol., $69: 14-59$

Illies J. 1972. - Emergenzmessung als neue Methode zur produktionsbiologischen Untersuchung von Flieflgewässern. - Verh. ber. 65. Jvers. dt. zool. Ges. : 65-68.

Illies J. 1980. - Ephemeropteren-Emergenz in zwei Lunzer Bächen (1972-1977). - Arch. Hydrobiol., 90 : 217-229.

Kazimírová.M. 1981. - Sezónna dynamika liahnutia a produkcia muskovitých (Simuliidae, Diptera) alpských potokoch. - Diplomarbeit, Naturwiss. Fak. Komenský Univ. Bratislava : 178 pp.

Kazimírová.M. 1982. - Die Beziehung zwischen dem Individualgewicht und einigen metrischen Merkmalen bei Eusimulium vernum (Macquart, 1826) (Simuliidae, Diptera). - Biológia (Bratisla va) $37: 973-977$

Kazimírová M. 1989. - Simuliiden-Emergenz in zwei Lunzer Bächen. - Verh. 9. SIEEC Gotha (1986) : 307-311.

Kimerle R.A. \& Anderson N.H. 1967. - Evaluation of aquatic insect emergence traps. - J. Econ. Ent., 60 : 1255-1259.

LeSage L. \& Harrison A.D., 1979. - Improved traps and techniques for the study of emerging aquatic insects. - Ent. News, $90: 65-78$.

Löhr P.-W. 1987. - Schwebfliegen (Diptera : Syrphidae) aus den Emergenzfallen der Limnologischen Flußstation in Schlitz am
Breitenbach (Schlitzerland). - Beitr. Naturk. Osthessen, 23 : 81-93.

Macan T.T. 1964. - Emergence traps and the investigation of stream faunes. Riv. Idrobiol., $3: 85-91$.

Malicky H. 1976. - Trichopteren-Emergenz in zwei Lunzer Bächen 1972-1974. - Arch. Hydrobiol., 77 : 51-65.

Malicky H. 1980. - Evidence for seasonal migrations of larvae of two species of philopotamid caddisflies (Trichoptera) in a mountain stream in Lower Austria. - Aquat. Insects, 2 : 153-160.

Malicky H. 1981. - Artificial illumination of a mountain stream in Lower Austria : Effect of constant daylight on the phenology of the caddisflies (Trichoptera). - Aquat. Insects, $3: 25-32$.

Malicky H. 1989. - Fünfzehn Jahre Emergenzuntersuchungen in Lunz, Niederösterreich. - Verh. 9. SIEEC Gotha 1986 : 311-316.

Malicky H. 1994. - Insekten-Emergenz eines permanenten Baches des eumediterranen Klimagebietes (Trichoptera, Ephemeroptera, Plecoptera). - Entomol. Gener,. 18 : 131-144.

Malicky H. 2002. (in press.) - A quantitative field comparison of emergence traps, with open and covered bottoms of a stream : general and Trichoptera. Ann. Limnol., 38.

Malicky H. \& Chantaramongkol P. 1995. - The altitudinal distribution of Trichoptera species in Mae Klang catchment on Doi Inthanon, northern Thailand : stream zonation and cool- and warmadapted groups. - Rev. hydrobiol. tropic., $26: 279-291$.

Morgan N.C. 1971. - Factors in the design and selection of insect emergence traps. In : Edmondson W.T. \& Winberg G.G. (eds) : A manual on methods for the assessment of secondary production in fresh waters. IBP handbook No. 17. Blackwell, Oxford. : 93-108.

Morgan N.C., Waddell A.B. \& Hall W.B. 1963. - A comparison of the catches of emerging aquatic insects in floating box and submerged funnel traps. - J. Anim. Ecol., $32: 203-219$.

Mundie J.H. 1971. - Techniques for sampling emerging aquatic insects. In : Edmondson W.T. \& Winberg G.G. (eds) : A manual on methods for the assessment of secondary production in fresh waters. IBP handbook No. 17. Blackwell, Oxford. : 80-93.

Plassmann E. 1984. - Sechs neue Pilzmücken aus Schweden, Österreich, Griechenland und Brasilien (Diptera, Nematocera, Mycetophilidae). - Nachrbl. Bayer. Ent., $33: 44-49$.

Ringe F. 1974. - Chironomiden-Emergenz 1970 in Breitenbach und Rohrwiesenbach. - Arch. Hydrobiol., Suppl. 45 : 212-304.

Röhner C. 1978. - Die Ephemeropterenemergenz vom Teichbach und Schreierbach aus den Jahren 1972-1975. - Wiss. Hausarbeit, Justus Liebig Univ. Gießen : 45 p.

Sprules M. 1947. - An ecological investigation of stream insects in Algonquin Park, Ontario. - Publ. Ontario Fish. Res. Lab., 69 : $1-81$.

Statzner B. \& Resh V. H. 1993. - Multiple-site and - year analyses of stream insect emergence : a test of ecological theory. - Oecologia, $96: 65-79$.

Steffan A.W. 1997. - Driftemergenz-Fanggeräte zur Erfassung schlüpfender Fließgewässer-Insekten (Ephemeroptera, Plecoptera, Trichoptera, Diptera). - Entomol. Gener., 21 : 293-306.

Straka V. \& Samietz R. 1992. - Terrestrische Tanzfliegen (Diptera ; Brachycera ; Empidoidea) der Familien Empididae und Hybotidae in der Vesser-Emergenz 1987. - Abh. Ber. Mus. Nat. Gotha, $17: 33-40$.

Wagner R. (without year). — Lunzer Psychodiden (Diptera, Psychodidae). - Diplomarbeit, Justus Liebig Univ.Gießen : 74 p.

Wagner R. 1980. — Lunzer Psychodiden (Diptera, Nematocera). Limnologica (Berlin), 12 : 109-119.

Wagner R. 1982. - Dipteren-Emergenz zweier Lunzer Bäche 1972 1974 nebst Beschreibung einer neuen Empidide (Diptera). - Arch. Hydrobiol., 95 : 491-506.

Wolda H. 1983. - "Long-term" stability of tropical insect populations. - Res. Popul. Ecol. Suppl., 3 : 112-126.

Zwick P. 1977. - Plecopteren-Emergenz zweier Lunzer Bäche, 1972-1974. - Arch. Hydrobiol,. 80 : 458-505. 